\title{
sciendo
}

DOI 10.2478/sbe-2020-0010

SBE no. 15(1) 2020

\section{A GENDERED STUDY OF ATTITUDE TOWARDS MONEY IN DELHI NCR}

\author{
MANCHANDA RIMPLE \\ GD Goenka University, Gurgaon, India
}

\begin{abstract}
:
Money Attitude determines the financial behavior of an individual. Both males and females are expected to demonstrate different money attitude due to difference in socialization and childhood orientations. This preliminary study attempts to determine the contrast in money attitude of males and females in Delhi and National Capital Region and present a comparative analysis in terms of their spending and saving habits. Data from 117 male respondents and 126 female respondents was collected. Money attitude was measured by adopting four sub-dimensions of Money Attitude Scale (MAS) developed by Yamauchi \& Templer (1982). Descriptive analysis and independent t-test has been devised to test the dissimilarity in money attitude between male and female in Delhi NCR. The results bring about contrast across gender in terms of the four sub-dimensions of MAS. The research has implications for marketers, sociologist, economists, psychologists, and financial planners. The further research can be extended in terms of demographic factors.
\end{abstract}

Key words: Money Attitude, Gender, Males, Females, Delhi-NCR

\section{Introduction}

Attitude has been defined as an unrelenting predisposition to experience and act in a constructive and unconstructive manner (Eagly \& Chaiken, 1993; Reitz, 1987). Behavior of a person depends on one's attitude. Attitude of a person shapes the way one behaves in a particular situation (Kruglanski, Jasko, Chernikova \& Milyavsky, 2018; Vogel \& Wanke, 2016; Rokeach, 1966). The relationship between ones attitude towards money and one's behavior in money matters is analogues to this attitude-behavior relationship. The manner in which attitude influences one's behavior; money attitude influences one's behavior in matters related to money (Britt, 2016; Taneja, 2012).

Money attitude is one's perception about money and how one behaves in matters related to money (Tang, 1988). It determines the financial behavior of an individual (Lindgren, 1980). Every individual has to take decisions involving money and has to deal with money implicitly or explicitly in all aspects of their life (Dowling, Tim \& Hoiles, 2009; Shim, Barber, Card, Xiao \& Serido, 2010; Lim, Teo \& Loo, 2003). 
The significance of study of attitude towards money comes in with the growing significance of money in individual's life. One needs money to survive. Thus, the attitude towards money takes imperative position (Taneja, 2012; Wilhelm, Varcoe, \& Fridrich, 1993)

The study of money attitude is significant because it entails money decisions and financial behavior (Manchanda, 2012; Dowling et al., 2009; Masuo, Kim, Malroutu \& Hanashiro, 2002; Lown \& Ju, 1992). In a metropolitan city like Delhi, people are struggling day and night to earn living. There is a constant effort for earning increasingly. Not only males but females also being the breadwinners, in majority of the families, are toiling equally as males (Neetha, 2004; Lim \& Teo, 1997).

The research has not just reported the increased earnings by females but has also conveyed the ever-increasing spending habits of females as compare to males (Hoddinott \& Haddad, 1995; Hayhoe, Leach, Turner, Bruin, \& Lawrence, 2000). These earning and spending habits are result of one's money attitude (Roberts \& Jones 2001; Phau \& Woo, 2008). In the society experiencing evolution and transition, money attitudes is comprehensible through people residing in that society, (Burgess, Battersby, Gebhardt \& Steven, 2005). Thus, it is important to study the contrast in money attitude of males and females.

This paper aims to perform a gendered study of money attitude. There had been studies on dissimilarity in money attitude among males and females, but no study has been conducted so far in Delhi NCR region. The main objective of this paper is to study and compare the attitude towards money of males and females in Delhi and National Capital Region and present a comparative analysis in terms of their spending and saving habits. Money attitude is raising apprehension for economists, psychologists, anthropologists, sociologists, and marketers and they are continuously showing their concern towards it.

\section{Literature review and hypothesis development}

People's attitude develops eventually and is inclined by experiences in the past as well as socialization (Manchanda, 2014; 2012). Prior research has shown numerous variables that are accountable for determining one's attitude towards money.

Money is central for good life and has been one of the top three priorities for most of the people (Rubenstein, 1981). It is a crucial element of our everyday living and existence. Sometimes it is taken as a cause for inapt behavior but all together it is the most desirable (Freud, 1959). Money is used as a contrivance to stimulate and get admiration (Fenichel, 1938). It shows achievement and success (McClelland \& Winters, 1971). People save money due to their inadequacies and anxiety (Adler, 1964). Attitude towards money influences the spending practices of an individual.

Money attitude has been defined by different social scientists at different points of time in literature. It has been described as a conception that has significance place and role to play in all aspects of life (Feldman, 1957); Money attitude has been portrayed through one's manifestation of success and attainment in life (Murray; 1938). It has been explained as a multi-dimensional concept (Yamauchi \& Templer, 1982); that reflects one's consideration for money (Tang, 1988); one's opinions and morals with regard to money 
(Prince, 1991) and reveals one's temperament or opinions relating to money (Rutherford \& DeVaney, 2009). It has been taken as a tool to aid financial happiness. It shows one's deliberation for prominence and self-image (Lindgren, 1980) and one's approach to determine one's sway. It works as a conduit of stimulation and disclose one's dependency on as well as apprehensions about money (Furnham, 1984, Taneja, 2012).

Undoubtedly, the attitude towards money keeps on fluctuating but there have been studies in past that confirm that previous involvements and socialization have key contribution in forming the attitude (Lim et al., 2003; Hira \& Mugenda, 2000; Eagly \& Chaiken, 1993) and it is as a result of dissimilarity in socialization that money attitude amongst males and females differs (Manchanda, 2013; Shim et al., 2010; Gutter, Copur \& Garrison, 2009; Newcomb \& Rabow, 1999; Hira, 1997).

Males and females tend to show different attitude towards money (Falahati \& Paim, 2011; Dowling, et al., 2009; Allen, Edwards, Hayhoe \& Leach, 2008; Lim, et al., 2003; Masuo et al., 2002, Hayhoe, et al., 2000; Hayhoe, Leach \& Turner, 1999). Both males and females are expected to demonstrate different attitude towards money due to difference in up-bringing and orientations (Hayhoe et al., 2000). The inferences in gender studies advocate that male's perception on money differs from that of female, which is attributable to difference in the way in which families treat their male and female children (Shim et al., 2010). Both have very different believes and opinions about money (Allen et al., 2008; Falahati \& Paim, 2011). This difference can be attributed to variance in socialization, childhood experiences, financial experiences (Lim et al., 2003; Dowling, et al., 2009). Both reflect different money behavior, sensitivity, and fulfillment (Hira \& Mugenda, 2000, Manchanda, 2015).

People generally encourage their male child to actively participate and contribute in the family (Newcomb \& Rabow, 1999). Studies have also shown that attitude towards money is also affected by financial adversities that one faces in the course of life. People who face financial adversities, tend to be more unstinting in helping others and often face financial anxiety. From the gendered perspective, males use money to make inferences and do evaluate about others whereas females do not (Lim \& Teo, 1997). The males were more apprehensive about the power and anxiety dimensions, whereas females were more worried about their family budget, personal budget, preservation and assessment (Lim et al., 2003). In a traditional society, where males are supposed to be the employed and earning member as well as the head of the family; they use money to show their power and prestige money attitude. Females on the other hand, embrace the family roles, are more concerned with budget and retention money dominants. Parents, peers and siblings have a vital part to play in the progression of dissimilar attitude towards money among males and females (Prince 1993a; Newcomb \& Rabow, 1999; Gutter et al., 2009; Shim et al., 2010).

Women take money as a means to have their cherished possession (Prince, 1993b). They are less knowledgeable on the subject matter (Goldsmith \& Goldsmith, 1997) and their concern about money is limited to themselves, as they do not have a narrow financial outlook. (Lim, et al., 2003). Females have been found to be fond of money as it brings them satisfaction but they also spend money and indulge in profligacy more than males (Lim et al., 2003; Falahati \& Paim, 2011). 
The study of money attitude is important because it significantly affects one's actions and reactions in money matters and monetary well-being. The socio-economic environment being dynamic tenders various concerns in terms of factors that nature buying and spending choices of the consumer (Sinha \& Banerjee, 2004; Kuruvilla \& Joshi, 2010). Based on the review of literature on concept of money attitude and evaluation of gendered studies on money attitude so far, the current study aims to study variance in money attitude of males and females in Delhi NCR. There have been gendered studies in relation to money attitude but none of the study has been done on Indian sample in general and sample form Delhi NCR in specific. To fill the gap in literature, hypotheses have been developed to investigate the gender difference in money attitude in terms of different dimensions of money attitude scale developed by Kent T Yamauchi and Donald I. Templer (1982) i.e. power-prestige; retention time; distrust and anxiety.

To study the dissimilarity in attitude of males and females of Delhi NCR towards use of money as a symbol of success and status, expecting that people use money as a tool to show their power and status in society, the first hypothesis to be tested is:

$\mathrm{H}_{01}$ : There is no significant difference in sample means of males and females for power/prestige dimension of money attitude scale.

$H_{o 1}=\overline{x_{M 1}}-\overline{x_{F 1}}=0$

Where,

$\overline{x_{M 1}}=$ Mean of power - prestige dimension for males;

$\overline{x_{F 1}}=$ Mean of power - prestige dimension for females.

The study further explores if there is difference in attitude of males and females of Delhi NCR towards future orientation and security in terms of money, expecting that people generally tend to save money for future unforeseen incidents. The second hypothesis is:

$\mathrm{H}_{02}$ : There is no significant difference in sample means of males and females for retentiontime dimension of money attitude scale

$$
H_{o 2}=\overline{x_{M 2}}-\overline{x_{F 2}}=0
$$

Where,

$\overline{x_{M 2}}=$ Mean of retention time dimension for males; $\overline{x_{F 2}}=$ Mean of retention time dimension for females.

To study the dissimilarity in attitude of males and females towards situations involving money expecting that people are generally hesitant, doubtful and suspicion in situations involving money. The third hypothesis is:

$\mathrm{H}_{03}$ : There is no significance difference in sample means of males and females for distrust dimension of money attitude scale.

$H_{o 3}=\overline{x_{M 3}}-\overline{x_{F 3}}=0$ 
Where,

$\overline{x_{M 3}}=$ Mean of distrust dimension for males;

$\overline{X_{F 3}}=$ Mean of distrust dimension for females.

To find out variance in attitude of males and females towards situations involving money; as both males and females are expected to feel anxious in situations involving money. The fourth hypothesis is:

$\mathrm{H}_{04}$ : There is no statistically significant difference in sample means of males and females for anxiety dimension of money attitude scale.

$H_{o 4}=\overline{x_{M 4}}-\overline{x_{F 4}}=0$

Where,

$\overline{x_{M 4}}=$ Mean of anxiety dimension for males;

$\overline{x_{F 4}}=$ Mean of anxiety dimension for females.

\section{Methodology}

The research is exploratory and descriptive in nature. Primary data has been collected through a self-administered survey questionnaire. The survey questionnaire comprises of a measures for assessing money attitude along with some demographic questions. The Money Attitude Scale (MAS) developed by Kent T Yamauchi and Donald I. Templer (1982) has been used to measure the money attitude of the sample. Money Attitude Scale is a 29-item scale, which has been authenticated several times empirically through previous research studies and is valid for the measurement of money attitude of Indian sample. This measurement scale comprises four sub-dimensions i.e. Power/Prestige, Retention Time, Distrust, and Anxiety. The power-prestige sub-dimension of money attitude scale indicates money as a symbol of recognition and accomplishment. Nine-item sub-dimension defines the usage of money as power and prestige. Individuals who attain high score on this sub-dimension be likely to use money as an instrument to influence and sway others. The retention-time sub-dimension of money attitude indicates concerned and thoughtful attitude for money. A seven-item sub-dimension quantifies one's watchful attitude towards money. People who score high on this dimension be susceptible to be future oriented and always look for financial security. The distrust sub-dimension of money attitude scale points out disbelieving attitude in monetary matters. Seven-item subscale measures the hesitant and worrisome behavior of people in relation to money and matters related to money. People who score high on this dimension have a tendency to be concerned for money. The anxiety sub-dimension of money attitude assesses the level of apprehension associated with monetary or pecuniary matters. This six-item sub-scale evaluates money as source of uneasiness. Individuals who score high on this subdimension be inclined to feel more apprehensive in money matters. The questionnaire has few demographic questions for capturing the information on age and gender. Five point Likert's scale was used to collect the data ranging from strongly disagree to strongly agree. The survey was conducted in Delhi and National Capital Region (Gurgaon, Noida, Faridabad). Data was collected using convenience sampling from respondents across 
different regions in Delhi National Capital Region. Total 400 questionnaires were distributed out of which 298 people responded to the survey. Out of 298, 55 questionnaires were incomplete as they either had missing responses or the data on gender was missing. Final 243 responses were used for the study. Out of these, 117 were males $(48.15 \%$ males) and 126 were females (51.85\% females). The average age of respondents was 29 years. Income wise, total 46 respondents earn upto Rs 2.5 lacs, 61 respondents earn Rs 2.5 to Rs 5.00 Lacs, 59 respondents fall in income category of Rs 5 Lacs to Rs 7.5 lacs, 48 respondents earn between Rs 7.5 to Rs 10.00 lacs and 20 earn above 10 lacs. Out of total 243, 135 respondents were from Delhi (55.56\% from Delhi) and 108 respondents were from National Capital Region (44.44\% from NCR). Table 1 gives the demographic information of the sample:

Table 1: Sample Demographic Information

\begin{tabular}{|c|c|c|c|c|c|c|}
\hline \multirow{2}{*}{\multicolumn{2}{|c|}{$\begin{array}{l}\text { Statistics } \\
\text { Groups Categorization / Levels }\end{array}$}} & \multicolumn{4}{|c|}{ Gender } & \multirow[b]{2}{*}{ Total } \\
\hline & & Males & $\%$ & Females & $\%$ & \\
\hline \multirow{6}{*}{ 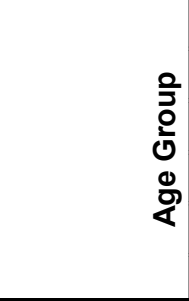 } & Upto 25 years & 21 & 18 & 23 & 18 & 44 \\
\hline & Above 25 to 30 years & 22 & 19 & 28 & 22 & 50 \\
\hline & Above 30 to 35 years & 24 & 21 & 29 & 23 & 53 \\
\hline & Above 35 to 40 years & 21 & 18 & 25 & 20 & 46 \\
\hline & Above 40 Years & 29 & 25 & 21 & 17 & 50 \\
\hline & Total & 117 & 48 & 126 & 52 & 243 \\
\hline \multirow{6}{*}{ 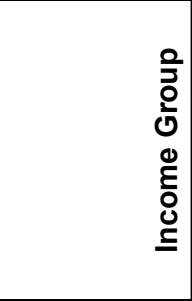 } & Upto Rs 2.5 Lacs & 19 & 16 & 27 & 21 & 46 \\
\hline & Rs. 2.5 to Rs 5.00 Lacs & 25 & 21 & 36 & 28 & 61 \\
\hline & Rs 5.00 Lacs to Rs 7.5 Lacs & 28 & 24 & 31 & 25 & 59 \\
\hline & Rs 7.5.00 Lacs to Rs 10 Lacs & 27 & 23 & 21 & 17 & 48 \\
\hline & Above 10 Lacs & 18 & 16 & 11 & 9 & 29 \\
\hline & Total & 117 & 48 & 126 & 52 & 243 \\
\hline \multirow{3}{*}{ 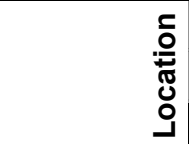 } & Upto Rs 2.5 Lacs & 19 & 16 & 27 & 21 & 46 \\
\hline & Rs. 2.5 to Rs 5.00 Lacs & 25 & 21 & 36 & 28 & 61 \\
\hline & Total & 117 & 48 & 126 & 52 & 243 \\
\hline
\end{tabular}

\section{Data analysis and discussion}

Descriptive statistics of all the four sub-dimensions has been summarized to give an exact depiction of sample. Table 2 gives the details of mean scores and standard deviation of males $(\mathrm{N}=117)$ and females $(\mathrm{N}=126)$. The mean score of power/prestige subdimension for males is 27.74 (8.583) and for females is 23.74 (9.432). The mean scores for males is little above the average score but that of females is quiet below the average, which shows that males have more tendency to use money to influence others. They see money as a symbol of success. Females would have fewer tendencies to use money as tool of power and prestige.

The mean score of retention time dimension for males is 25.77 (6.317) and for females is 28.50 (7.327). Though both the mean scores are above the average score, the 
means score of retention time dimensions is higher for females which shows that females have higher tendencies to save money for future.

\section{Table 3: Descriptive Statistics}

\begin{tabular}{|l|l|l|l|}
\hline Gender (N) & Males (N=117) & Females (N=126) & Total (N=243) \\
\hline Money Attitude Sub-dimensions & Mean $(\mathrm{SD})$ & Mean $(\mathrm{SD})$ & Mean $(\mathrm{SD})$ \\
\hline \multirow{2}{*}{ Power/Prestige } & $\overline{x_{M 1}}\left(\sigma_{\mathrm{M} 1}\right)$ & $\overline{x_{F 1}}\left(\sigma_{\mathrm{F} 1}\right)$ & $\overline{x_{1}}\left(\sigma_{1}\right)$ \\
& $27.74(8.583)$ & $23.74(9.432)$ & $25.74(9.006)$ \\
\hline \multirow{2}{*}{ Retention Time } & $\overline{x_{M 2}}\left(\sigma_{\mathrm{M} 2}\right)$ & $\overline{x_{F 2}}\left(\sigma_{\mathrm{F} 2}\right)$ & $\overline{x_{2}}\left(\sigma_{2}\right)$ \\
& $25.77(6.317)$ & $28.5(7.327)$ & $27.14(6.914)$ \\
\hline \multirow{2}{*}{ Distrust } & $\overline{x_{M 3}}\left(\sigma_{\mathrm{M} 3}\right)$ & $\overline{x_{F 3}}\left(\sigma_{\mathrm{F} 3}\right)$ & $\overline{x_{3}}\left(\sigma_{3}\right)$ \\
\hline \multirow{2}{*}{ Anxiety } & $19.56(6.637)$ & $16.27(4.851)$ & $17.93(6.037)$ \\
& $\overline{x_{M 4}}\left(\sigma_{\mathrm{M} 4}\right)$ & $\overline{x_{F 4}}\left(\sigma_{\mathrm{F} 4}\right)$ & $\overline{x_{4}}\left(\sigma_{4}\right)$ \\
\hline
\end{tabular}

The mean and standard deviation of distrust dimension for males is 19.56 (6.637) and females is 16.27 (4.851). Though both the mean scores are below the average score, the means score of distrust dimension is higher for males.

The mean score of anxiety dimension for males is 16.79 (5.961) and for females is 19.75 (5.154). The mean scores of females is above the average score and that of males is below the average score. The means score of anxiety dimension is higher for females which means that females feel more apprehensive in money matters.

To find out differences in attitude towards money among males and females, the mean comparison t-test was carried out between male and female respondents. An independent-samples t-test conducted to compare difference in attitude towards money between males and females gave results that variability in males and female group does not significantly different for power/prestige, retention-time and anxiety sub-dimension but variability in males and females groups is significantly different for distrust dimension.

Table 4 shows the results for independent sample t-test. T-test results show that there is statistically significant difference between mean scores of males and females for power/prestige sub-dimension $\left(\mathrm{t}_{(241)}=1.804 ; \mathrm{p}\right.$-value $\left.=0.022\right)$, retention time sub-dimension $\left(t_{(241)}=2.401, p\right.$-value $\left.=0.017\right)$, distrust sub-dimension $\left(t_{(241)}=4.087, p\right.$-value $\left.=0.000\right\}$ and anxiety sub-dimension $\left(\mathrm{t}_{(241)}=2.642, \mathrm{p}\right.$-value $=0.009 \mathrm{\}}$ as $\mathrm{p}$-value for all the sub-dimensions is less than 0.05 .

Table 4: The Results for t-test

\begin{tabular}{|l|l|l|}
\hline & $\mathrm{t}_{(241)}$ & Sig. (2 tailed) \\
\hline Power/prestige & 1.804 & .022 \\
\hline Retention time & 2.401 & .017 \\
\hline Distrust & 4.087 & .000 \\
\hline Anxiety & 2.642 & .009 \\
\hline
\end{tabular}

*df: 241 
The results have confirmed the studies on money attitude conducted earlier. There is a difference in attitude towards money between males and females (Manchanda, 2013; Dowling, et al., 2009; Lim, et al., 2003; Hayhoe et al., 1999).

These results suggest that gender really does have an effect on attitude towards money for power and prestige, retention time, distrust and anxiety sub-dimensions of money attitude (Falahati \& Paim, 2011; Allen et al., 2008; Masuo et al., 2002, Hayhoe, et al., 2000;). Specifically, our results suggest that both males and females do differ when it comes to using money as a symbol of power and prestige thus we reject the first null hypothesis and can say that there is a significant difference in attitude of males and females towards use of money as a symbol of success and status.

The same is reflected through difference in the means of males and females samples for power/prestige dimension of money attitude scale. $\left(\overline{x_{M 1}}>\overline{x_{F 1}}\right)$. Males have higher tendency to use money as a symbol of power and prestige since their mean score is higher.

The current research findings also confirm with the previous research outcomes that males are more ardently involved to use money as a means to demonstrate their power-prestige in society then females (Falahati \& Paim, 2011).

The males and females have shown significant difference in terms of saving money for future, thus we reject the second null hypothesis. There is a statistically significant difference in money attitude of males and females towards future orientation and security in terms of money. This confirms the previous research of (Lim et al., 2003; Roberts, 1999; Furnham, 1984) that says that males do save for future uncertainties and females tend to save more due to their conservative mentality about money.

This also gets confirmed from means values of males and females for retentiontime dimension of money attitude scale $\left(\overline{x_{M 2}}<\overline{x_{F 2}}\right)$. Females are more future oriented and look for financial security for future than males. Thet have been found more conscious about future financial security than males. (Lim et al., 2003).

Males and females also significantly differ in monetary situations that involve trusting people around them. Males do not trust people easily in case of money matters. Males are more hesitant, doubtful and suspicion in situations involving money. There is a difference in sample means of males and females for distrust dimension of money attitude scale. $\left(\overline{x_{M 3}}>\overline{x_{F 3}}\right)$. There are studies that show that males are more secure and poised about money (Rubinstein, 1981), which might not work due to cultural and social differences in sample.

For anxiety sub-dimension, a difference was found in sample means among males and females $\left(\overline{x_{M 4}}<\overline{x_{F 4}}\right)$. The results prove that females feel more anxious in situations involving money than males. Previous research had shown that males display more optimistic attitudes toward money than females (Tang, 1988); but simultaneously they also have combat anxiety. The current results may not confirm to earlier gendered studies because of difference in culture, socialization etc. and are more anxious than males (Goldsmith \& Goldsmith, 1997; Oleson, 2004; Wilhelm, et. al., 1993). 


\section{Implications}

The research highlights the grounds on which males and females attach importance to money and different roles that money plays in their life. The current research contributes to the analysis of consumer comportment and behavior (Prince, 1991). People with different money attitudes illustrate diverse purchase and spending behavior.

The results show that when the power-prestige sub-dimension of money attitude becomes stronger, the consumer develops the habit of purchasing and spending more (Zsótér, \& Németh, 2017; Rimple, Srikant, Naseem, \& Kumar, 2015). However, at the same time if retention -time and distrust sub-dimensions of money attitude pronounce, the person tends to spend less. This makes consumer conservative. This way the research highlights the direct and significant association between money attitude and consumer buying behavior. This helps the marketers in strategizing the about placement, marketing and promotion of gender specific products. In addition, it facilitates marketers in manipulating the endorsement of different products to make it desirable across gender.

The analysis would also be useful for sociologist, economists, and psychologists as the study sheds light on the amount of significance people attach to money varies across gender. This helps sociologists in understanding the gaps and resemblance among different gender groups in terms of money. It helps economist in making gender specific policy recommendations. The psychologist would be able to understand and interpret the contrast in the financial behavior of males and females in a better way.

Study has implications for the financial planners, as they need to understand how people's money attitude is associated with and affect their speculation, investment hoarding and savings behavior. It offers an indication to them for delivering relevant advises and to augment their pecuniary skills.

\section{Conclusion, limitations and future scope of study}

Examination of money attitude provide insight into behaviors of consumer in financial and money related subjects such as saving, investment, creation of assets, liability, impetuous buying, conspicuous consumption etc. (Hanley \& Wilhelm, 1992; Lau, Furnham \& Okamura, 1999; Roberts \& Jones, 2001; Roberts \& Sepulveda, 1999; Rousseau \& Venter, 1999; Hayhoe et. al.,1999; Lim, 2003; Norvilitis, Merwin, Osberg, Roehling, Young, \& Kamas, 2006; Chi \& Banerjee, 2013). The affirmative money attitude leads to cheerful and satisficing behaviors such as living a contented life. It keeps one from liabilities (Beutler \& Gudmunson, 2012; Gudmunson \& Beutler, 2012). The pessimistic money attitude crops up the unnecessary spending behaviors. Being high on powerprestige, anxiety, and distrust sub-dimension (Roberts \& Jones, 2001) inclines one in the direction of carrying out unnecessary money practices consequently, which ultimately increases anxiety.

This research supports the basic hypothesis of the previous studies. The difference found among males and females may perhaps is the result of difference in socialization (Shim et al., 2010; Newcomb \& Rabow, 1999). The males in Indian society 
are always given open hand in terms of money decision. This kind of socialization make them more confident in money matters as compare to females (Gutter et al., 2009).

The study was limited to males and females residing in Delhi NCR. Further studies can be conducted on different sample. Similar studies on money attitude can be conducted with respect to different age groups, education level, profession, income level etc. The prospective study on different regions and different sample set can further bring about the contrasts and similarities in societies. The money attitude of different cultures, societies and groups highlights their ethics and beliefs that prevail in societies and how they affect the money attitude of people associated with them.

\section{References}

Adler, A. (1964). Problems of Neurosis: A Book of Case Histories. New York: Harper \& Row.

Allen, M. W., Edwards, R., Hayhoe, C. R., \& Leach, L. (2008). Imagined interactions, family money management patterns and coalitions, and attitudes toward money and credit. Journal of Family and Economic Issues, 28(1), 3-22.

Beutler, I., \& Gudmunson, C. (2012). New adolescent money attitude scales: Entitlement and conscientiousness. Journal of Financial Counseling and Planning, 23(2).

Britt, S. L. (2016). The intergenerational transference of money attitudes and behaviors. Journal of Consumer Affairs, 50(3), 539-556.

Burgess, S. M., Battersby, N., Gebhardt, L., \& Steven, A. (2005). Money attitudes and innovative consumer behavior: Hedge funds in South Africa. ACR North American Advances.

Chi, Y. N., \& Banerjee, G. (2013). Empirical Analysis of Bicultural Border College Students' Attitudes Toward Money. Journal of Applied Business and Economics, 14(3), 70-82.

Dowling, N., Tim, C., \& Hoiles, L. (2009). Financial management practices and money attitudes as determinants of financial problems and dissatisfaction in young male Australian workers. Journal of Financial Counseling and Planning, 20(2), 5-13.

Eagly, A. H., \& Chaiken, S. (1993). The psychology of attitudes. Orlando, FL, US: Harcourt Brace Jovanovich College Publishers.

Falahati, L., \& Paim, L. H. (2011). A comparative study in money attitude among university students: a gendered view. Journal of American Science, 7(6), 1144-1148.

Feldman, F.L. (1957). A New Look at the Family and its Money. Journal Of Home Economics, 49, 767-772

Fenichel, O. (1938). The Drive To Amass Wealth. Psychoanalytic Quarterly, 7(1), 69-95.

Freud, S. (1959). Family Romances. In The Standard Edition Of The Complete Psychological Works Of Sigmund Freud, Volume Ix (1906-1908): Jensen's 'Gradiva' and Other Works, 235-242.

Furnham, A. (1984). Many Sides Of The Coin: The Psychology Of Money Usage, Personal And Individual Differences, 5, 501-509.

Furnham, A., \& Okamura, R. (1999). Your money or your life: Behavioral and emotional predictors of money pathology. Human relations, 52(9), 1157-1177.

Goldsmith, E., \& Goldsmith, R. E. (1997). Gender differences in perceived and real knowledge of financial investments. Psychological Reports, 80(1), 236-238.

Gudmunson, C. G., \& Beutler, I. F. (2012). Relation of parental caring to conspicuous consumption attitudes in adolescents. Journal of Family and Economic Issues, 33(4), 389-399.

Gutter, M., Copur, Z., \& Garrison, S. T. (2009). Which students are more likely to experience financial socialization opportunities? Exploring the relationship between financial behaviors and financial well-being of college students Indiana: Networks Financial Institute, Indiana University. 
Hanley, A., \& Wilhelm, M. S. (1992). Compulsive buying: An exploration into self-esteem and money attitudes. Journal of economic Psychology, 13(1), 5-18.

Hayhoe, C. R., Leach, L. J., Turner, P. R., Bruin, M. J., \& Lawrence, F. C. (2000). Differences in spending habits and credit use of college students. Journal of Consumer Affairs, 34(1), 113133.

Hayhoe, C. R., Leach, L., \& Turner, P. R. (1999). Discriminating the number of credit cards held by college students using credit and money attitudes. Journal of economic psychology, 20(6), 643-656.

Hira, T. K. (1997). Financial attitudes, beliefs and behaviours: differences by age. International Journal of Consumer Studies, 21(3), 271-290.

Hira, T. K., \& Mugenda, O. (2000). Gender differences in financial perceptions, behaviors and satisfaction. JOURNAL OF FINANCIAL PLANNING-DENVER-, 13(2), 86-93.

Hoddinott, J., \& Haddad, L. (1995). Does female income share influence household expenditures? Evidence from Côte d'Ivoire. Oxford Bulletin of Economics and Statistics, 57(1), 77-96.

Kruglanski, A. W., Jasko, K., Chernikova, M., \& Milyavsky, M. (2018). The rocky road from attitudes to behaviors: Charting the goal systemic course of actions. In The Motivated Mind(pp. 261306). Routledge.

Kuruvilla, S. J., \& Joshi, N. (2010). Influence of demographics, psychographics, shopping orientation, mall shopping attitude and purchase patterns on mall patronage in India. Journal of Retailing and Consumer Services, 17(4), 259-269.

Lim, V. K., \& Teo, T. S. (1997). Sex, money, and financial hardship: An empirical study of attitudes towards money among undergraduates in Singapore. journal of Economic Psychology, 18(4), 369-386.

Lim, V. K., Teo, T. S., \& Loo, G. L. (2003). Sex, financial hardship and locus of control: an empirical study of attitudes towards money among Singaporean Chinese. Personality and Individual Differences, 34(3), 411-429.

Lindgren, H. C. (1980). Great Expectation: The Psychology Of Money. Los Altos: Williams Kaufmann, Inc.

Lown, J. M., \& Ju, I. S. (1992). A model of credit use and financial satisfaction. Financial Counseling and Planning, 3(1), 105-124.

Manchanda, R, (2012), MONEY ATTITUDE - AN ABRIDGEMENT, Journal of Arts, Science \& Commerce, III (3) 94

Manchanda, R. (2013). An Investigation of Disparity of Money Attitude Across Gender And Organizational Set Up, Management Guru: Journal of Management; II (1), 56-69

Manchanda, R. (2014). Money Attitude: An Impact of Socialization in India. Proceeding of: International Seminar on Inequality and an attempts at bridging them: Past and Present, Noida International University

Manchanda, R. (2015). Impact of Socialization on Attitude towards Money: A Review. Pragyaan: Journal of Management, 19.

Masuo, D., Kim, J. H., Malroutu, L., \& Hanashiro, R. (2002). Money beliefs and behaviors: A comparison of Asian and Asian American female college students. Journal of Asian Regional Association of Home Economics, 9, 223-227.

Mcclelland, D. C., \& Winter, D. G. (1971). Motivating Economic Achievement: Accelerating Economic Development Through Psychological Training. New York: Free Press

Murray, H. A. (1938). Explorations In Personality. New York: Oxford University Press

Neetha, N. (2004). Making of female breadwinners: Migration and social networking of women domestics in Delhi. Economic and Political Weekly, 1681-1688.

Newcomb, M. D., \& Rabow, J. (1999). Gender, socialization, and money. Journal of Applied Social Psychology, 29(4), 852-869. 
Norvilitis, J. M., Merwin, M. M., Osberg, T. M., Roehling, P. V., Young, P., \& Kamas, M. M. (2006). Personality factors, money attitudes, financial knowledge, and credit-card debt in college students 1. Journal of applied social psychology, 36(6), 1395-1413.

Oleson, M. (2004). Exploring the relationship between money attitudes and Maslow's hierarchy of needs. International journal of consumer studies, 28(1), 83-92.

Phau, I., \& Woo, C. (2008). Understanding compulsive buying tendencies among young Australians: The roles of money attitude and credit card usage. Marketing Intelligence \& Planning, 26(5), 441-458.

Prince, M. (1991). Gender And Money Attitudes Of Young Adults. Gender And Consumer Behavior. Conference Proceedings. 284-291.

Prince, M. (1993a). Women, Men, And Money Styles. Journal Of Economic Psychology, 14(3), 175182.

Prince, M. (1993b). Self-Concept, Money Beliefs And Values, Journal Of Economic Psychology, 14, 161-173.

Reitz, H. J. (1987). Behavior in organizations. Homewood, III.: Richard D Irwin, p 250

Rimple, M., Srikant, M., Naseem, A., \& Kumar, M. J. (2015). A study of interaction of materialism and money attitude and its impact on car purchase. Management \& Marketing, 10(3), 245-269.

Roberts, J. A. (1999). Demographics and money attitudes: a test of Yamauchi and Templers (1982) money attitude scale in Mexico. Personality and individual Differences, 27(1), 19-35

Roberts, J. A., \& Jones, E. (2001). Money attitudes, credit card use, and compulsive buying among American college students. Journal of consumer affairs, 35(2), 213-240.

Roberts, J. A., \& Sepulveda M, C. J. (1999). Money attitudes and compulsive buying: an exploratory investigation of the emerging consumer culture in Mexico. Journal of International Consumer Marketing, 11(4), 53-74.

Rokeach, M. (1966). Attitude change and behavioral change. Public Opinion Quarterly, 30(4), 529550.

Rousseau, G. G., \& Venter, D. J. L. (1999). Measuring consumers attitudes towards money. South African Journal of Economic and Management Sciences, 2(3), 407-422.

Rubinstein, C. R. (1981). Survey Report On Money. Psychology Today, 15 (5), 29 - 44

Rutherford, L., \& Devaney, S. A. (2009). Utilizing The Theory Of Planned Behavior To Understand Convenience Use Of Credit Cards. Journal Of Financial Counseling And Planning, 20(2).

Shim, S., Barber, B. L., Card, N. A., Xiao, J. J., \& Serido, J. (2010). Financial socialization of firstyear college students: The roles of parents, work, and education. Journal of youth and adolescence, 39(12), 1457-1470.

Sinha, P. K., \& Banerjee, A. (2004). Store choice behavior in an evolving market. International Journal of Retail \& Distribution Management, 32(10), 482-494.

Taneja, R. M. (2012). Money attitude-an abridgement. Researchers World, 3(3), 94.

Tang, T. L. P. (1988). The Meaning Of Money Revisited: The Development Of The Money Ethic Scale

Vogel, T., \& Wanke, M. (2016). Attitudes and attitude change. Psychology Press.

Wilhelm, M. S., Varcoe, K., \& Fridrich, A. H. (1993). Financial satisfaction and assessment of financial progress: Importance of money attitudes. Financial Counseling and Planning, 4(1), 181-198.

Yamauchi, K. T., \& Templer, D. J. (1982). The Development Of A Money Attitude Scale. Journal of Personality Assessment, 46(5), 522-528.

Zsótér, B., \& Németh, E. (2017). Characterisation of Young People According to Their Financial Attitudes and Behaviours-A Survey on the Financial Behaviour and Attitudes of Students in Higher Education. Applied Finance and Accounting, 4(1), 31-40. 